\title{
Uso de baterías alcalinas agotadas para activar carbón de granza de arroz
}

\author{
Use of spent alkaline batteries to activate rice husk carbon
}

\author{
Jose Leitons iD \\ Universidad de Costa Rica
}

OPEN 2 ACCESS

Recibido: 05/08/2021

Aceptado: 07/10/2021

Publicado: 29/11/2021

Correspondencia de autores: jose.leiton@ucr.ac.cr

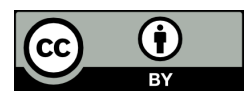

Copyrith 2020 by Investigación e Innovación en Ingenierías
Resumen

Objetivo: Utilizar desechos agroindustriales y baterías alcalinas agotadas como materia prima para producir carbón activado. Metodología: Como primer paso, granza de arroz fue calcinada por 6 horas a $300{ }^{\circ} \mathrm{C}$ en atmósfera de nitrógeno. Posteriormente fue activada a $600{ }^{\circ} \mathrm{C}$ por dos horas luego de ser inmersa en una disolución de ácido clorhídrico y cloruro de zinc [1,0 mol L-1]. El cloruro de zinc se obtuvo al tratar la pasta interna de baterías alcalinas agotadas con ácido clorhídrico [3,0 mol L-1]. En contraste, los activadores hidróxido de potasio, extraído de las baterías alcalinas agotadas, y el dióxido de carbono gaseoso no produjeron carbón activado bajo las mismas condiciones. Las fibras de la hoja de piña no produjeron carbón activado cuando fueron sujetas a las condiciones descritas anteriormente. Resultados: Carbón activado de granza de arroz con una superficie de 315 m2 g-1 y rico en sílice amorfo. Conclusiones: Es posible convertir granza de arroz en carbón activado con la ayuda de cloruro de zinc obtenido de baterías alcalinas descartadas. El uso de dos desechos para producir carbón activado no está descrito en la literatura científica. Se requiere más ensayos para determinar las condiciones que producirán carbón activado con la mayor superficie.

Palabras clave: Carbón activado, baterías alcalinas agotadas, granza de arroz.

Abstract

Objective: Objective: Use agro-industrial waste and spent alkaline batteries as raw materials to produce activated carbon. Methodology: As a first step, rice husk was calcinated in a nitrogen atmosphere at $300{ }^{\circ} \mathrm{C}$ for six hours. Then activated after being soaked in a solution of hydrochloric acid and zinc chloride at $600{ }^{\circ} \mathrm{C}$ for two hours under a nitrogen atmosphere. Zinc chloride [1.0 mol L-1] was obtained by treating the inner paste of spent alkaline batteries with hydrochloric acid [3.0 mol L-1]. In contrast, neither potassium hydroxide, extracted from spent alkaline batteries, nor gaseous carbon dioxide produced activated carbon under the same conditions. Pineapple leaf fiber was also tested but failed to produce activated carbon under any of the conditions described. Results: Activated carbon, rich in heterogeneous silica with a surface area of $315 \mathrm{~m} 2 \mathrm{~g}-1$ was produced using rice husk. Conclusions: It is possible to convert rice husk waste into activated carbon with the aid of zinc chloride obtained from discarded alkaline batteries. The use of two wastes to produce activated carbon is not described in the scientific literature. Further tests on the conditions to produce higher surface is required.

Keywords: Activated carbon, spent alkaline batteries, rice husk.

Como citar (IEEE): J. Leiton "Uso de baterías alcalinas agotadas para activar carbón de granza de arroz", Investigación e Innovación en Ingenierías, vol. 9, $n^{\circ} 1,221-227,2021$. DOI: https://doi.org/10.17081/invinno.9.2.5542 


\section{Introduction}

Activated carbon (AC) includes a wide range of processed carbon-based materials that have a highly developed porosity and an extended interparticulate surface area with an amorphous structure [1]. AC may contain other elements such as oxygen, sulfur, hydrogen, nitrogen, and halogens bonded chemically to the structure. Oxygen is found to be predominant element which exist in the form of functional groups such as carboxyl, carbonyl, phenols, lactone and others [2]. There are three properties of AC that control their adsorption characteristics: the distribution of pore sizes within the carbon, the mean pore size and the composition of the surfaces which contain the porosity. Pore widths typically range from $<1.0 \mathrm{~nm}$ to $50 \mathrm{~nm}$, with surface compositions varying from graphitic to oxygenated polar surfaces [3]. According to IUPAC classification, pore with width not exceeding $2.0 \mathrm{~nm}$ is considered micropore, from $2 \mathrm{~nm}$ to $50 \mathrm{~nm}$ are considered mesopores and bigger than $50 \mathrm{~nm}$ are macropores [4]. The pore size is affected by the temperature, duration of the activation process and activation method [5]. The smaller the pore the higher the surface area, this can be determined using the Brunauer-Emmett-Teller (BET) method, which measures nitrogen adsorption at different pressures at the temperature of liquid nitrogen.

AC is commonly prepared by two basic methods: physical or gas activation and chemical activation. The selection of the method depends upon the starting material and whether a low or high density, powdered or granular carbon is desired [6]. For the chemical method, the carbonized raw material is first impregnated with chemical reagents, such as phosphoric acid, zinc chloride, alkaline hydroxides, and ferric chloride [7] and later activated at temperatures that range from $200^{\circ} \mathrm{C}$ to $1000^{\circ} \mathrm{C}$ [2]. Activated carbon has many uses: in medicine, it can be used to treat drug overdoses [8], it can be used to remove dyes and metal ions from aqueous solutions [9], remotion of contaminants from soil, air, water[10], gas streams and support for catalysts [11]. Lately, other potential applications have been described by Nadeem et al. [12] and include the use of AC in electrochemical capacitors, lithium ion batteries, solar cells, fuel cells and hydrogen and carbon dioxide storage systems.

Commercial AC normally uses raw materials such as petroleum residues, wood, coconut shells, coal, peat and lignite. Recently, the use of agricultural waste and inexpensive lignocelluloses materials has drawn attention [2]. In the case of Costa Rica, there is potential of using lignocellulose residues from forestry and waste from the production of palm oil and pineapple [13]. Banana [14], rice, sugar cane and coffee waste are also potential sources of carbon [15]. Rice husk, discarded from the rice milling process, has a reported mass composition of $66.67 \%$ carbon, $22.30 \% \mathrm{SiO} 2,7.10 \% \mathrm{H}_{2} \mathrm{O}, 0.82 \mathrm{Al}_{2} \mathrm{O}_{3}, 0.78 \% \mathrm{Fe}_{2} \mathrm{O}_{3}, 1.10 \% \mathrm{~K}_{2} \mathrm{O}, 0.78 \% \mathrm{Na}_{2} \mathrm{O}$, $0.24 \% \mathrm{CaO}$ and $0.21 \% \mathrm{MgO}$, this composition varies depending on the crop location and soil preparation. The composition is not homogeneous because the amorphous silica, also refereed as opaline silica, is concentrated in the protuberances and hairs on the outer and inner epidermis of the husk [16].

Along agricultural waste, Costa Rica also deals with domestic and industrial waste, including the waste generated by 2340 tons of batteries imported yearly [17, 18]. Table 1 shows that spent batteries are potential source for some of the chemicals used to activate carbon such as potassium hydroxide (KOH) and zinc ( $\mathrm{Zn}$ ) which can be transformed to zinc chloride $\left(\mathrm{ZnCl}_{2}\right)$ using hydrochloric acid $(\mathrm{HCl})$. 
Table 1. Chemical composition of the most common Duracell alkaline battery.

\begin{tabular}{|c|c|c|c|c|c|}
\hline & $9 \mathrm{~V}$ & D & C & $\mathbf{A A}$ & AAA \\
\hline Mass/g & 45 & 141 & 67 & 22 & 11 \\
\hline \multicolumn{6}{|c|}{ Percentual composition } \\
\hline Lead $(\mathrm{Pb})$ & $<0.04$ & $<0.04$ & $<0.04$ & $<0.04$ & $<0.04$ \\
\hline Zinc $(Z n)$ & 11 & 18 & 17 & 16 & 15 \\
\hline $\begin{array}{c}\text { Manganese oxide } \\
(\mathrm{MnO} 2)\end{array}$ & 27 & 43 & 40 & 37 & 35 \\
\hline Graphite (C) & 3 & 5 & 5 & 4 & 4 \\
\hline $\mathrm{KOH}$ solution & 12 & 18 & 18 & 17 & 17 \\
\hline Nickel plated Steel & 18 & 10 & 14 & 17 & 19 \\
\hline Brass & 6 & 0.3 & 0.6 & 2 & 5 \\
\hline Plastic & 0.2 & 1 & 1 & 1 & 3 \\
\hline
\end{tabular}

Source: Duracell [19].

The revalorization of waste is of vital importance for a nation that is producing municipal waste at a rate of $390 \mathrm{~kg} /$ person-year [20].

The objective of this study was to use two types of waste to generate an AC that has commercial value. It was hypothesized that the chemicals in the alkaline batteries would be capable to activate rice husk and fiber from the pineapple leaves.

\section{Methods and materials}

Ten AA size alkaline batteries of different brands were crushed, their paste was collected and washed with one liter of hot distilled water. The liquid was filtered, resulting in a colorless solution with $\mathrm{pH}$ 12.9. The remaining black solid, insoluble in water, was washed with $0.1 \mathrm{~L}$ of hydrochloric acid solution $3.0 \mathrm{~mol} \mathrm{~L}^{-1}$, yielding a straw-colored solution rich in zinc ions $\left(1 \mathrm{~mol} \mathrm{~L}^{-1}\right)$ with traces of iron, manganese and copper.

Prior to activation, all agricultural waste samples were carbonized for six hours at $300{ }^{\circ} \mathrm{C}$ in a nitrogen atmosphere flowing at $15 \mathrm{~mL} / \mathrm{min}$. Three methods were tested to try to produce AC using the carbonized rice husk and pineapple leaf fiver, one physical and two chemical. The physical method used employed $\mathrm{CO}_{2}$ as activator for two hours at $600{ }^{\circ} \mathrm{C}$. One of the chemical methods used $\mathrm{KOH}$ obtained from the alkaline batteries and the second used $\mathrm{HCl}$ and the $\mathrm{ZnCl}_{2}$ solution also obtained from the alkaline batteries waste as previously described. These solutions were used separately to infuse two calcined samples of two grams each, for eight hours before being activated at $600^{\circ} \mathrm{C}$ for two hours under a nitrogen atmosphere.

Only the rice husk samples treated with $\mathrm{HCl}$ and $\mathrm{ZnCl}_{2}$ showed mesopores when observed under a Hitachi S-3700N Scanning Electronic Microscope, this sample was further analyzed using X-ray crystallography and ATR-FTIR spectrophotometry. 


\section{Results}

Figure 1. Calcined rice husk at $600^{\circ} \mathrm{C}$ treated with $\mathrm{ZnCl} 2$ and $\mathrm{HCl}$. 15 thousand magnifications.

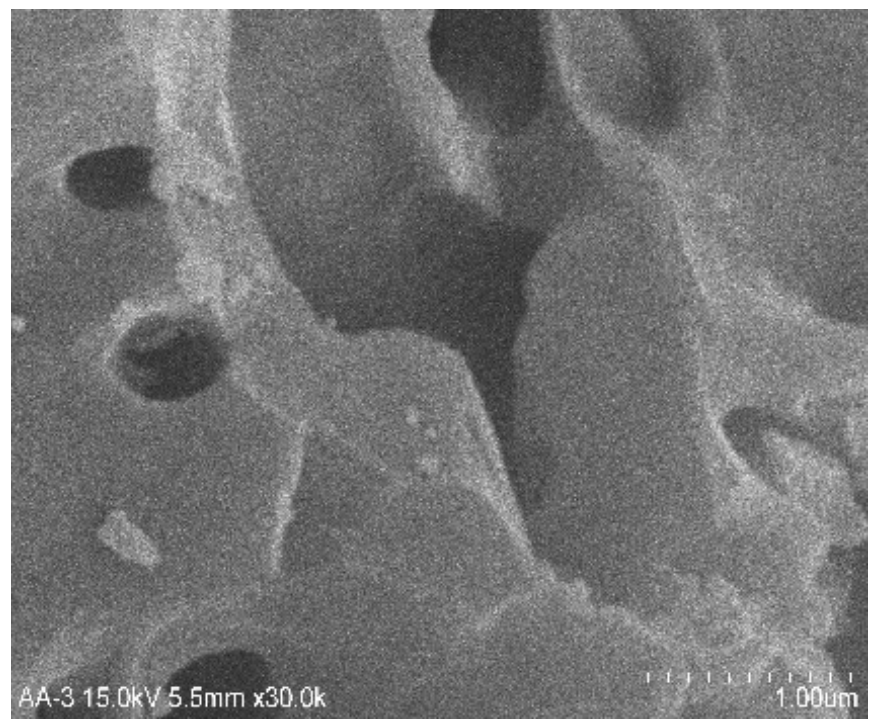

Source: CIEMic-UCR with sample from author.

Figure 2. Calcined rice husk at $600^{\circ} \mathrm{C}$ treated with $\mathrm{ZnCl}_{2}$ and $\mathrm{HCl}$. 30 thousand magnifications.

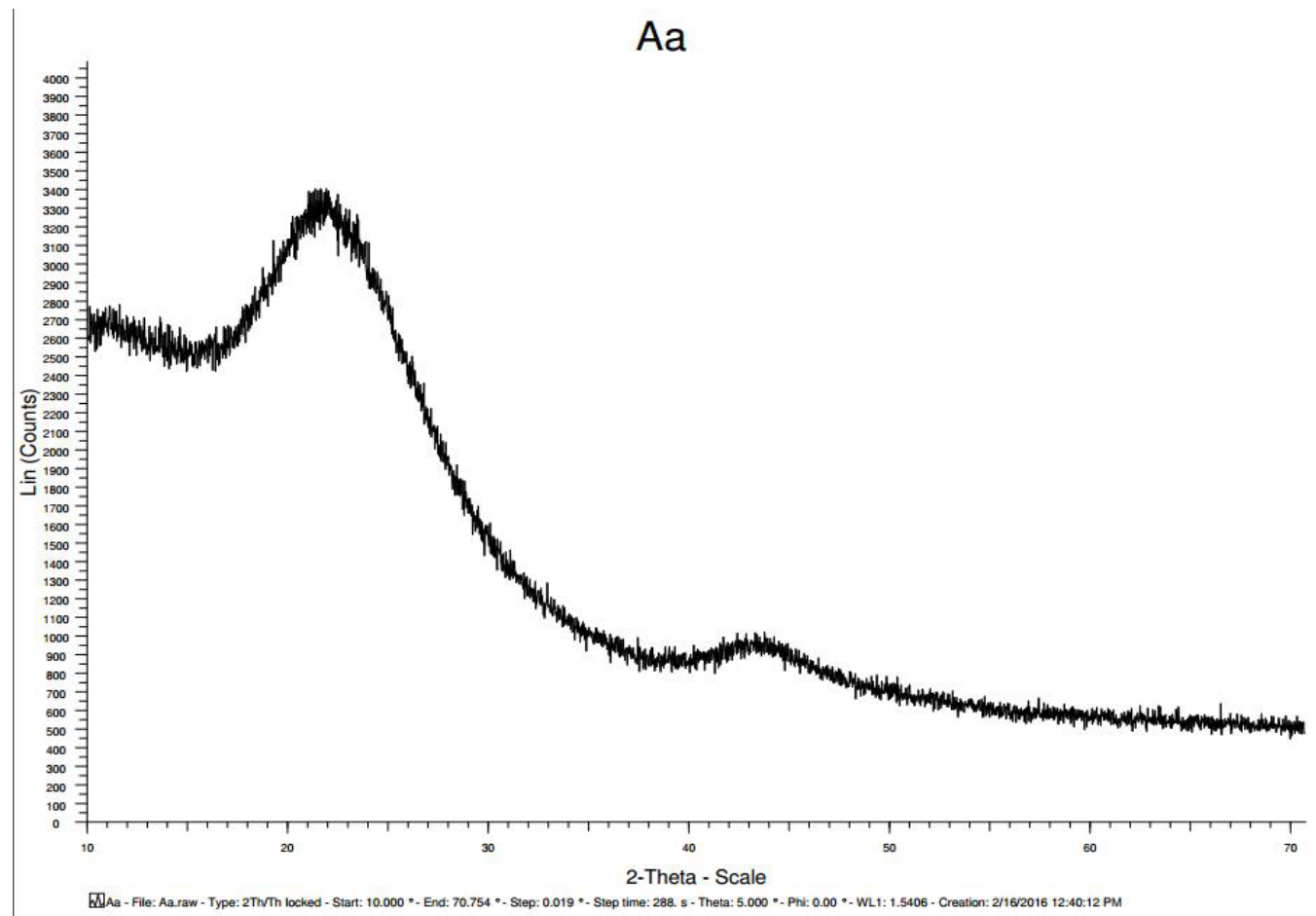

Source: CIEMic-UCR with sample from author. 
Figure 3. XRD spectra of rise husk activated with $\mathrm{HCl}$ and $\mathrm{ZnCl}_{2}$.

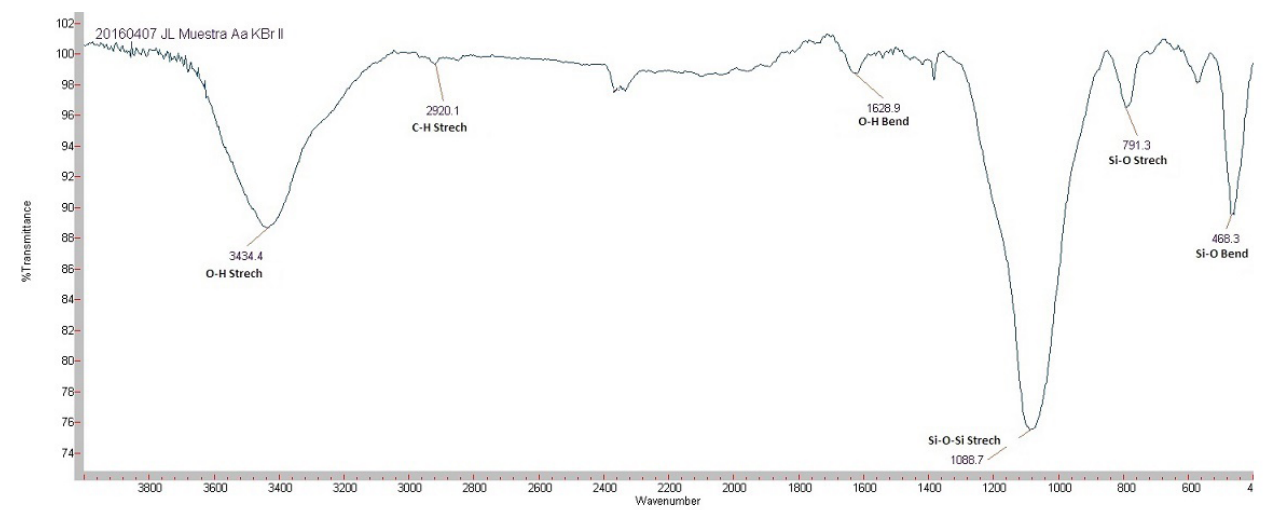

Source: Laboratorio de Rayos-X, Escuela de Química, UCR.

Figure 4. FTIR spectra in KBr for the activated rice husk. Data of the bulk powder.

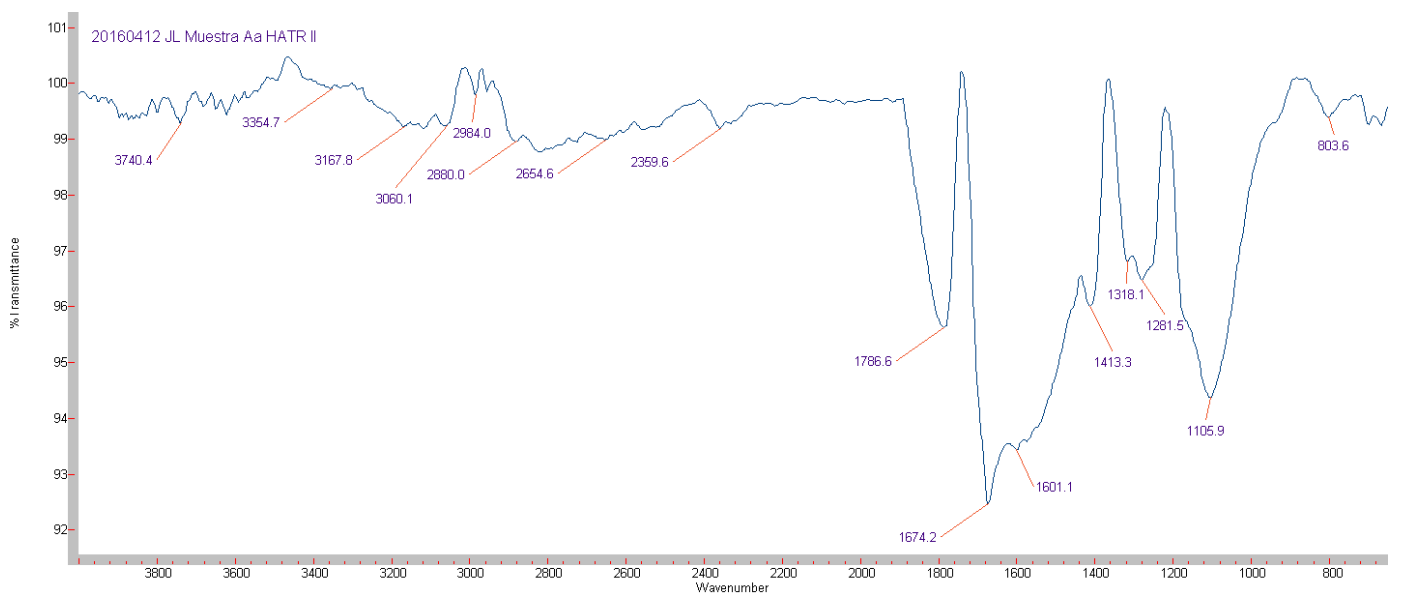

Source: Cuarto de Instrumentos, Escuela de Química, UCR.

\section{Discussion}

Figure 1 and 2 show SEM images of mesopores that are characteristic of activated carbon, this is in contrast with what was found by Rinawati et al. [21] who asserted that silica must be removed first from rice husk in order to obtain activated carbon. The surface area of $315 \mathrm{~m}^{2} \mathrm{~g}^{-1}$ obtained by BET also confirms surface activation, although areas ten times as big have been reported [6].

XRD spectra in Figure 3, shows a broad diffraction peak centered at $2 \theta=22^{\circ}$ indicating that the activated carbon contains abundant amorphous silica which is consistent with data from Mon [22]. IR spectra, in Figure 4, show the presence of Si-O bonds in the $\sim 1100 \mathrm{~cm}^{-1}$ region. The difference between IR spectra of 
the bulk powder and the surface indicates that the activated carbon surface is hydrophobic in nature due to the absence of the $3434 \mathrm{~cm}^{-1}$ band and the presence of hydrophobic aromatic groups as indicated by the strong bands between 1300 and $1800 \mathrm{~cm}^{-1}$, the strongest band at $1600 \mathrm{~cm}^{-1}$ corresponds to the stretching of the carbonyl $(u C=0)$ groups present in the hemicelluloses and lignin aromatic groups. These bands are barely noticeable in the bulk IR spectra which has a pronounced $\mathrm{O}-\mathrm{H}$ band at $3434 \mathrm{~cm}^{-1}$. The heterogeneous composition of rice husk is consistent with results presented by Alam et al [16].

\section{Conclusions}

Zinc chloride prepared from discarded alkaline batteries could be used to activate carbon obtained from rice husk. This is the first time that such procedure has been reported in the scientific literature. Further experiments need to be carried out to study the influence of time, temperature and $\mathrm{ZnCl}_{2}$ concentrations on pore distribution. It is expected that further pore development could be achieved at higher temperature and increased time of calcination.

\section{Bibliographic References}

1. Koehlert. K. “Activated carbon: Fundamentals and New applications" Chemical Eng, Jul. 2017, pp. 32-40. [Online]. Available: https://tinyurl.com/carbon-activado

2. Yahya, M. A., Al-Qodah, Z., Ngah, C. W. Z., "Agricultural bio-waste materials as potential sustainable precursors used for activated carbon production: A Review." Renewable and Sustainable Energy Reviews, vol. 46, pp.218-235. Jun. 2015. DOI: https://doi.org/10.1016/j.rser.2015.02.051

3. Bubanale, S. "History, Method of Production, Structure and Applications of Activated Carbon“ Int. J. of Eng. Res. \& Tech. vol. 6, no. 6, pp. 495-498. Jun. 2017. [Online]. Available: https://www.ijert.org/research/ history-method-of-production-structure-and-applications-of-activated-carbon-IJERTV6IS060277. pdf

4. McNaught, A. D. and Wilkinson. A. IUPAC Compendium of Chemical Terminology, $2^{\text {nd }}$ ed. UK: Blackwell Scientific Publications. Jul. 2019. [Online]. Available: http://goldbook.iupac.org.

5. Van, K. L. and Thu, L. T. "Preparation of Pore-Size Controllable Activated Carbon from Rice Husk Using Dual Activating Agent and Its Application in Supercapacitor“ Hindawi J. of Chemistry, pp. 1-11, Jan. 2019. [Online], DOI: https://doi.org/10.1155/2019/4329609.

6. Ukanwa, K., S., Patchigolla, K., Sakrabani, R., Anthony, E. and Mandavgane S., "A Review of Chemicals to Produce Activated Carbon from Agricultural Waste Biomass“ Sustainability, vol. 11, p. 6204, Nov. 2019. [Online] DOI: https://doi.org/10.3390/su11226204.

7. Vidal, M. V., Rodríguez A., Martínez, K., Ocampo, J. and Barrios W. "Potencial de residuos agroindustriales para la síntesis de Carbón Activado: una revisión“ Scientia et Technica, vol. 23, pp. 411-419, Set. 2018.

8. Zellner, T., Prasa, D., Färber, E., Hoffmann-Walbeck, P., Genser, D. and Eyer F. “The Use of Activated Charcoal to Treat Intoxications“ Dtsch. Artzbl. Int., vol. 116, no. 8, pp 311-317, May 2019. DOI: https:// doi.org/10.3238/arztebl.2019.0311

9. Tareq, R., Akter, N., Azam, S. “Chapter 10 - Biochars and Biochar Composites: Low-Cost Adsorbents for Environmental Remediation." in Biochar from Biomass and Waste. Ed. Elsevier, 2019, pp. 169-209. [Online] DOI: https://doi.org/10.1016/B978-0-12-811729-3.00010-8 
10. Kaur, H., Hippargy, G., Pophali, G. and Bansiwal, A. K. "Chapter 6 - Treatment methods for removal of pharmaceuticals and personal care products from domestic wastewater." in Biochar from Biomass and Waste. Ed. Elsevier, 2019, pp. 129-150. [Online] DOI: https://doi.org/10.1016/B978-0-12-8161890.00006-8

11. Cao, X, Sun, S. and Sun, R. "Application of biochar-based catalysts in biomass upgrading: a review" RSC Advances, vol. 7, pp. 48793-48805, Oct. 2017. DOI: https://doi.org/10.1039/c7ra09307a

12. Nadeem, F., Hussain, S., Tiwari, P., Goswami, A. and Ustun, T. "Comparative Review of Energy Storage Systems, Their Roles, and Impacts on Future Power Systems." IEEE Access, no. 7, pp. 4555-4585. Jan. 2019. DOI: https://doi.org/10.1109/ACCESS.2018.2888497.

13. Aragón-Garita, S., Moya, R., Bond, B., Valaert, J. and Filho M. T. "Production and quality analusis of pellets manufactured from five potential energy crops in the Northern Region of Costa Rica."Biomas and Bioenergy, no. 87, pp. 84-95, Apr. 2016. DOI: https://doi.org/10.1016/j.biombioe.2016.02.006

14. Barz, M., Delivand, M. K., Dinkler, K. "Agricultural Wastes -A Promising Source for Biogas Production in Developing Countries of the Tropical and Subtropical Regions" Revista Forestal Mesoamericana Kurú, vol 16, no. 38, pp. 02-12, Jan. 2019. DOI: https://doi.org/10.18845/rfmk.v16i38.3991.

15. Amirza, M., Adib, M., Hamdam, R. "Application of Agricultural Wastes Activated Carbon for Dye Removal -An Overview." in MATEC Web of Conferences, 2017. DOI: https://doi.org/10.1051/matecconf/201710306013

16. Alam, M., Hossain, A., Hossain, D., Johir, A. H., Hossen, J., Rahman, S., Zhou, J., Hasan, A., Ka,akar, A., K. and Ahmed, M, B. "The Potentiality of Rice Husk-Derived Activated Carbon: From Synthesis to Application“Processes, vol. 8, no. 2, pp. 1-39. Feb. 2020. DOI: https://doi.org/10.3390/pr8020203

17. INEC. Importaciones de baterías. [Database]. Available: http://sistemas.inec.cr/SICCE_Hacienda/SICCE_ Hacienda/.

18. PEN. Estado de la Nación 2019. [Online]. Available: https://estadonacion.or.cr/informes/.

19. Duracell. "Duracell Typical Chemical Composition." Accessed: Feb. 10, 2020: [Online]. Available: http:// tinyurl.com/Duracell-composition.

20. OECD Economic Surveys Costa Rica 2018 [Online]. Available: https://www.comex.go.cr/media/6035/finalenglish-survey-cr-2018.pdf

21. Rinawati R., Hidayat, D., Supriyanto, R., Permana D. F. and Yunita R. D. (2019) "Adsorption of Polycyclic Aromatic Hydrocarbons using Low-Cost Activated Carbon Derived from Rice Husk. "J. of Physics: Conf. Series. [Online]. Available: https://iopscience.iop.org/article/10.1088/1742-6596/1338/1/012005/pdf.

22. Mon, E. E. "Study on the Silica from Rice Husk Ash by XRD and XRF" Int. J. od Scientific \& Eng. Res., vol. 9, no. 6, pp. 1535-1537. Jun. 2018. [Online]. Available: https://www.ijser.org/researchpaper/Study-on-theSilica-from-Rice-Husk-Ash-by-XRD-and-XRF.pdf 